\title{
TEN GELEIDE
}

\section{Een computer stapt nooit met het verkeerde been uit bed, maar kan hij ook straffen opleggen?}

\author{
Sigrid van Wingerden
}

Een computerprogramma dat de straf van een dader bepaalt. Dat klinkt als een ingrediënt van een slechte sciencefictionfilm, maar met de invloedrijke rol die artificial intelligence (AI) al speelt in de samenleving, is het reëel dat AI vroeg of laat aan de poorten van de rechtspraak klopt. In Nederland hebben we al kennisgemaakt met computerprogramma's ter ondersteuning van de rechter die de beslissing neemt. Een voorbeeld daarvan is de Databank Consistente Straftoemeting, die rechters konden raadplegen voor hun straftoemetingsbeslissing. Ook zijn we bekend met het gebruik van risicotaxatie-instrumenten die geconsulteerd worden bij bijvoorbeeld beslissingen over de schorsing van de voorlopige hechtenis. Daarnaast is legal tech in opkomst: op basis van data van eerdere zaken en uitspraken doet een computerprogramma voorspellingen over de uitkomst van een zaak. Maar van een computer die op de stoel van de rechter gaat zitten en zelfstandig de straf bepaalt, willen wij (nog) niet weten. Wij hebben liever dat een rechter van vlees en bloed de straftoemetingsbeslissing neemt: die heeft het dossier gelezen en foto's van slachtofferletsel gezien. En die heeft de verdachte - als hij aanwezig was - vragen gesteld en in de ogen gekeken. Bovendien kunnen rechters met hun uitspraak een morele boodschap overbrengen waarmee de afkeuring van het gedrag van de dader wordt uitgedrukt.

Toch weten we ook dat rechters bij hun straftoemetingsbeslissing niet onfeilbaar zijn. Rechters zijn mensen, met eigen ervaringen, voorkeuren, meningen en percepties. Juist het feit dat rechters mensen zijn, zorgt ervoor dat er ongerechtvaardigde verschillen in de straftoemeting kunnen ontstaan. Gezien het gelijkheidsbeginsel zou het voor de verdachte niet uit moeten maken of zijn zaak wordt behandeld door rechter Jan uit Amsterdam of door rechter Wilma uit Groningen. Toch bestaan die verschillen in de praktijk wel.

Voorstanders van de robotrechter wijzen er dan ook op dat AI de consistentie van de straftoemeting ten goede komt. De computer stapt nooit met het verkeerde been uit bed, heeft niet net ruzie gehad met zijn partner en heeft nooit slecht geslapen. Ook kan AI gebruikt worden om bestaande ongelijkheid in de straftoe-

* Mr. dr. Sigrid van Wingerden is als universitair docent Criminologie verbonden aan het Instituut voor Strafrecht \& Criminologie van de Universiteit Leiden. Zij is tevens voorzitter van de redactie van $P R O C E S$. 
meting tegen te gaan. Om ervoor te zorgen dat het geslacht van de verdachte bijvoorbeeld geen rol speelt bij de straftoemeting kan de computer aan vrouwen een 'strafbonus' geven - of aan mannen een 'strafkorting'. Etnisch gerelateerde verschillen in de straftoemeting kunnen op deze manier ook genivelleerd worden. AI kan zo tot minder ongelijkheid in de straftoemeting leiden, ook bijvoorbeeld voor wat betreft straftoemetingsverschillen tussen arrondissementen.

Straffen zullen dus consistenter worden, maar worden ze ook 'juister'? Tegenstanders van de robotrechter geven aan dat AI werkt met data die al vertekend zijn: alle onwenselijkheden die in de data zitten, zoals bewuste of onbewuste discriminatie, worden door het systeem gereproduceerd. Als de data die de computer gebruikt gebiast zijn, zijn de uitkomsten van het AI-systeem dat ook. Wellicht kan dit probleem worden overkomen door self learning-AI. Bij self learning-AI zijn er geen voorgeprogrammeerde regels meer nodig: het systeem leert steeds van zijn eigen beslissingen. Bij een zelfrijdende auto bijvoorbeeld leert het systeem zo steeds beter om aanrijdingen te voorkomen. Maar de vraag is of dit ook voor de rechtspraak kan gelden. Of een straftoemetingsbeslissing 'juist' was, is niet zo duidelijk als bij een zelfrijdende auto die een botsing wil voorkomen: ${ }^{1}$ het zou toch door een rechter beoordeeld moeten worden. Maar van die beslissingen van rechters weten we dat die niet altijd zo consistent zijn. Hoe moet de computer dan weten wat een juiste beslissing was? Daar komt nog bij dat beslissingen van self learning-AI niet transparant zijn. Er is dus niet na te gaan waarom de robotrechter tot een bepaalde straftoemeting komt, maar hier valt tegen in te brengen dat een individuele straftoemetingsbeslissing van een rechter van vlees en bloed eigenlijk ook een black box is.

Zou in de toekomst een computer beter in staat zijn om morele beslissingen te nemen dan mensen? Hebben we in de toekomst dan ook zoveel vertrouwen in de morele oordelen van de robotrechter dat die deze morele boodschap waarin afkeuring over het delictgedrag wordt uitgedrukt ook over kan brengen? Vooralsnog zien we straftoemeting als mensenwerk. Moeten we in de toekomst de robotrechter omarmen? De meeste sciencefictionfilms scheppen geen utopisch beeld van een wereld waarin AI de boel heeft overgenomen...

Machine learning staat ook centraal in de eerste bijdrage van dit nummer van PROCES. Patricia Prüfer en Emile Kolthoff laten zien hoe big data met behulp van machine learning-methoden onderzocht kunnen worden om bloot te leggen welke bedrijventerreinen een hoog risico hebben dat er georganiseerde criminaliteit en ondermijning voorkomt. Datascience kan zo een instrument zijn voor bestuurders die deze vormen van criminaliteit willen tegengaan. De auteurs wijzen erop dat er in de toekomst nog heel veel mogelijkheden liggen voor datascience om ook andere vormen van criminaliteit te voorspellen.

1 Hoewel Jan Maarten Elbers me erop wees dat zelfrijdende auto's ook moeten leren om morele beslissingen te nemen: als een botsing onvermijdelijk is, maar de auto kan bijvoorbeeld kiezen tussen het aanrijden van een bejaarde man of het ontwijken van de bejaarde maar zelf met drie kinderen op de achterbank tegen een boom aan knallen, moet ook de AI van de zelfrijdende auto in staat zijn om morele keuzes te maken. Zie ook A. Karsemijer, 'Zijn dit de langetermijneffecten van algoritmen?', Rechtstreeks 2019, 2, p. 35-38. 
De tweede bijdrage in dit nummer van PROCES is van Janine Janssen en Elisa van Ee. In het vorige nummer van PROCES namen zij enkele misverstanden over posttraumatische stressstoornis (PTSS) weg: PTSS is geen synoniem voor alle vormen van trauma, de diagnose PTSS biedt geen verklaring voor alle ellende, en EMDR is niet de enige behandelingsmogelijkheid. In dit vervolgartikel richten de auteurs zich op misverstanden over trauma bij professionals in de veiligheidszorg. Zij wijzen erop dat een professional niet zelf direct betrokken hoeft te zijn geweest om een trauma op te lopen en dat voor de behandeling van trauma steun van de sociale omgeving belangrijk is. Familie zou daarom ook bij de behandeling betrokken moeten worden.

Vervolgens schetsen Maria Berghuis, Hanneke Palmen en Paul Nieuwbeerta op basis van gegevens van de Life in Custody-studie een beeld van de regels en praktijk van het bezoeken van gedetineerden in de gevangenis. Hoeveel gedetineerden ontvangen bezoek? En hoe vaak krijgen zij bezoek? Wat zijn de effecten daarvan voor de gedetineerde tijdens en na detentie? De auteurs wijzen erop dat het ontvangen van bezoek zowel positief als negatief kan uitpakken voor de gedetineerden en voor hun re-integratie. Relaties die naast sociale steun ook instrumentele steun bieden dienen gestimuleerd te worden, en het spanningsveld tussen het stimuleren van sociale netwerken en veiligheidsrisico's verdient nog meer aandacht in de wetenschap en in de praktijk.

Hierna volgt de vaste rubriek PROCESperikel, waarin deze keer Michelle Pape en Marco Brok schrijven over het werk van Bureau Buitenland van de reclassering, dat ondersteuning biedt aan Nederlanders die in het buitenland zijn gedetineerd. Vrijwilligers spelen daarbij een belangrijke rol. Volgens Pape en Brok is het van belang om reclasseringsvrijwilligers te professionaliseren zonder afbreuk te doen aan de 'eigenheid' van die vrijwilligers.

De twee artikelen die daarop volgen richten zich beide op de schuldenproblematiek van delinquenten. Het hebben van schulden is een risicofactor voor het plegen van criminaliteit, en andersom is criminaliteit een risicofactor voor het hebben van schulden. Om criminaliteit te voorkomen is het dus belangrijk om oog te hebben voor schulden. In de eerste bijdrage richten Gercoline van Beek, Vivienne de Vogel en Dike van de Mheen zich op de schulden onder reclasseringscliënten. Aan de hand van een systematische literatuurreview naar de relatie tussen financiële problematiek en delinquentie en aan de hand van dossieronderzoek naar de prevalentie en omvang van de schulden onder cliënten van de reclasseringsorganisaties concluderen de auteurs onder andere dat informatie over de financiële situatie van een cliënt vaak ontbreekt en dat cliënten vaak geen financiële begeleiding hebben. Meer aandacht voor financiële problemen in resocialisatieprogramma's zou kunnen helpen om terugval te voorkomen.

Schulden staan ook centraal in de bijdrage van Rosa Koenraadt, Anja Dirkzwager en Paul Nieuwbeerta. Zij beschrijven op basis van data uit het Prison Project hoe schulden van gedetineerden er voor, tijdens en na detentie uitzien: gedetineerden hebben verschillende typen schulden en er bestaan grote verschillen in de hoogte van de schulden. Als het verband tussen schulden en criminaliteit wordt onderzocht, zou met deze verschillen rekening gehouden moeten worden. 
Ten slotte beschrijft Janine Janssen in de rubriek PS van een redacteur dat er twee decennia na het opheffen van het bordeelverbod nog altijd geen consensus is over de moraal in het sekswerk. In de discussie met zedenpredikers aan het ene uiterste en voorvechters van zelfbeschikking aan het andere uiterste pleit Janssen ervoor om in het debat ook vooral naar de stem van de sekswerkers te luisteren. 